\title{
Erythrocyte Cell Morphology
}

National Cancer Institute

\section{Source}

National Cancer Institute. Erythrocyte Cell Morphology. NCI Thesaurus. Code C92296.

An examination or assessment of the form and structure of red blood cells. 